\title{
Humanized childbirth: the values of health professionals in daily obstetric care
}

\author{
Parto humanizado: valores de profissionais de saúde no cotidiano do cuidado obstétrico \\ Parto humanizado: valores de los profesionales de salud en la atención obstétrica diaria
}

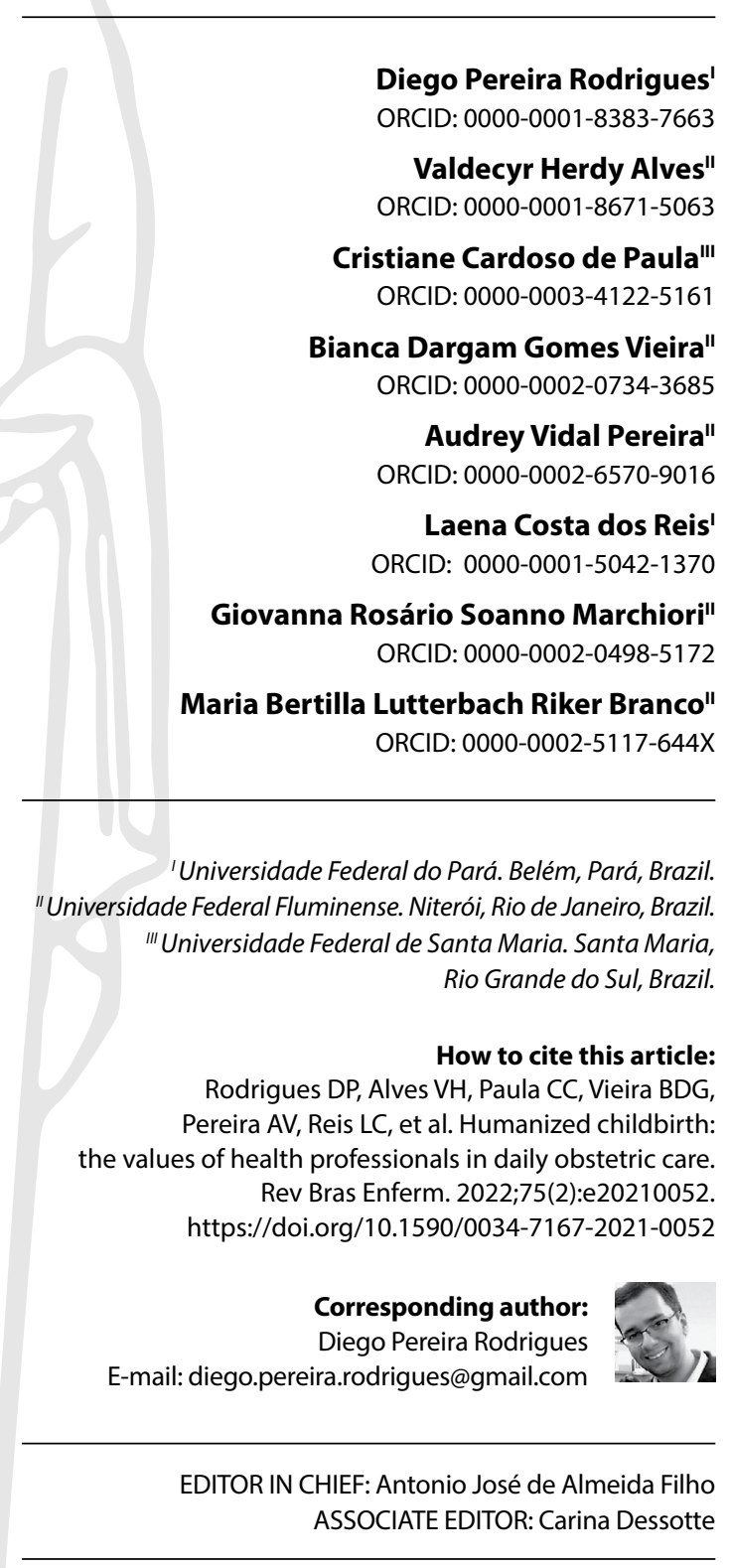

Submission: $02-22-2021$

Approval: 06-06-2021

\begin{abstract}
Objective: To understand health professionals'values in the process of thinking and feeling about obstetric care, based on their experienced needs in the care process. Methods: Phenomenological study based on the Schelerian framework, with 48 health professionals from four maternity hospitals within the Metropolitan Region II of the state of Rio de Janeiro. Data collection was done through a phenomenological interview; and the analysis, with the Ricoeurian methodological framework. Results: The vital value was signified in care centered on physiological processes, for an individualized and safe monitoring. The ethical value was signified in the attitudes that provide women with autonomy in their way of giving birth, and recognize dialogue as a process of sympathy, affection, and bonding. Conclusion: The resignification of obstetric practice, articulated with public policies in the field of delivery and birth, supported by a vital ethical value, positively contributes to the humanization of care for women.
\end{abstract}

Descriptors: Maternal-Child Health Centers; Delivery of Health Care; Obstetric Nursing; Obstetrics; Philosophy, Nursing.

\section{RESUMO}

Objetivo: Compreender os valores dos profissionais de saúde no processo de pensar e sentir do cuidado obstétrico, baseando-se em suas carências vivenciadas no processo de cuidar. Métodos: Estudo fenomenológico fundamentado no referencial scheleriano, com 48 profissionais de saúde de quatro maternidades da Região Metropolitana II do estado do Rio de Janeiro. A coleta de dados foi por entrevista fenomenológica; e a análise, com o referencial metodológico ricoeuriano. Resultados: O valor vital foi significado no cuidado centrado nos processos fisiológicos, para um acompanhamento individualizado e seguro. O valor ético foi significado nas atitudes que oportunizam autonomia da mulher em sua forma de parir e reconhecem o diálogo como processo de relação de simpatia, afetividade e criação de vínculo. Conclusão: A ressignificação da prática obstétrica, articulada com as políticas públicas no campo do parto e nascimento, sustentada por um valor vitalético, contribui positivamente na humanização do cuidado às mulheres.

Descritores: Centros de Saúde Materno-Infantil; Parto Humanizado; Enfermagem Obstétrica; Obstetrícia; Filosofia em Enfermagem.

\section{RESUMEN}

Objetivo: Comprender valores de profesionales de salud en el proceso de pensar y sentir del cuidado obstétrico, basándose en sus carencias vividas en el proceso de cuidar. Métodos: Estudio fenomenológico fundamentado en el referencial scheleriano, con 48 profesionales de salud de cuatro maternidades de la Región Metropolitana II de Rio de Janeiro. Recolecta de datos fue por entrevista fenomenológica; y el análisis, con referencial metodológico ricoeuriano. Resultados: El valor vital fue significado en el cuidado centrado en procesos fisiológicos, para un acompañamiento individualizado y seguro. El valor ético fue significado en actitudes que posibilitan autonomía de la mujer en su manera de parir y reconocen el diálogo como proceso de relación de simpatía, afectividad y construcción de vínculo. Conclusión: La resignificación de la práctica obstétrica, articulada a políticas públicas en el campo del parto y nacimiento, sustentada por un valor vital-ético, contribuye positivamente en la humanización del cuidado a mujeres.

Descriptores: Centros de Salud Materno-Infantil; Parto Humanizado; Enfermería Obstétrica; Obstetricia; Filosofía en Enfermería. 


\section{INTRODUCTION}

Through World Health Organization (WHO) and the Ministry of Health $(\mathrm{MH})$ initiative, childbirth care has been transformed over the years on a global level and in Brazil, with the formulation of guidelines for normal childbirth, aimed at the review of knowledge, conduct, and obstetric practices in the field of childbirth ${ }^{(1-2)}$. These changes are the result of the collective construction of the movement initiated by women, professionals, health administrators, and researchers since the 1980s in favor of maternal and child health. Such changes allowed for a redefinition of the obstetric practices of health professionals, in line with Schelerian values ${ }^{(3-6)}$, that is, supported by respect, quality of care, protagonism, autonomy, women's satisfaction, safety, and care anchored in scientific evidence $^{(7-11)}$. However, the excess of unnecessary interventions is still part of daily care, including in maternity hospitals in Brazil.

Women undergo numerous obstetric procedures, such as episiotomy, Kristeller's maneuver, medicalization of oxytocics, trichotomy, enema, in addition to the cesarean epidemic in the country $^{(2,7-14)}$. Studies point to obstacles in the organizational structure of work management and professional attitudes, which are sometimes discriminatory, prejudiced, violent and inconsistent with good practices in childbirth care and with evidence-based practice $^{(8,12-14)}$, going against the biopsychosocial needs of women and their care values ${ }^{(4-6,15-18)}$.

Therefore, the movement for the humanization of childbirth has expanded public health policies in the reproductive field since the 2000s to qualify maternal and childcare and provide dignified and respectful care for women, encouraging their autonomy and protagonism, guaranteeing their sexual, reproductive, and human rights, as well as their values ${ }^{(3-6,15-18)}$. This movement enabled a line of interventions consistent with Goal 5 (Improving maternal health) of the Millennium Development Goals (MDGs); and currently with Goal 3 (Health and well-being) of the Sustainable Development Goals (SDGs).

Among these interventions is the creation of public policies such as: Programa de Humanização no Pré-natal e Nascimento [Prenatal and Birth Humanization Program] (PBHP) ${ }^{(10)}$; Política Nacional de Humanização [National Humanization Policy] (NHP) ${ }^{(19-20)}$; Estratégia Rede Cegonha [Stork Network Strategy] ${ }^{(11,20)}$; in addition to the new MH's National Guidelines for Assistance to Normal Childbirth ${ }^{(21)}$. Such policies promoted accessibility and resoluteness; expansion of obstetric care; construction/renovation of units; training/alteration of professional conduct; reorganization of the work process with an emphasis on the collaborative model of a multidisciplinary team; encouragement of normal/natural/physiological childbirth; and reduction of obstetric interventions ${ }^{(22)}$, with the valuation of subjectivity, individuality of care and of women's values and expectations $s^{(3-6,15-18)}$.

The meaning of humanization involves attitudes, practices, conducts and behaviors based on the healthy development of the delivery and birth processes, with a respect for individuality, uniqueness, and appreciation of women ${ }^{(8)}$. This humanization is aimed at service users, health professionals, and managers, with the aim of achieving quality and safety in delivery and birth care. Thus, the humanization of care movement, with emphasis on humanized childbirth, sought to realign women's autonomy versus the power over women's bodies centered on health professionals through institutional norms ${ }^{(13-14)}$.

Thus, humanization in childbirth care processes enables the opening of dialogues in the field of knowledge, in health practices, and in the established ways of health work ${ }^{(19)}$. Such modes are established in/with the co-responsibility process for the transformation of the work reality itself and in the set of actors. This highlights the close relationship between senses, motivation, satisfaction, and perception of value ${ }^{(3-6)}$ that configures the aspects of live work ${ }^{(23)}$.

From this perspective, Scheler's philosophical understanding makes room for analysis of the current context of humanization in the Brazilian scenario. The evaluative conception points out that value is everything that is esteemed for the human being ${ }^{(24-25)}$ and that, in the intuitive dimension, it is valid for the person's life ${ }^{(26)}$. Every value added by the person is intended to fulfill their needs, anxieties, and experiences ${ }^{(24)}$, represented here in the parturition process. This process is from the world of life, and the values are experienced by every person involved. In the conceptual dimension of his theory, three points are important:value, countervalue, and non-value. According to Scheler's thinking, everything that has a sense of opposition to value constitutes the countervalue, as we can illustrate: in being of value, "health", and the countervalue, the "partaking in inadequate nutrition", with consumption of harmful fats and ultra-processed products, this diet is an opposition to the "health" value; and the non-value means the total indifference to the "health" value ${ }^{(24)}$.

The study emerged based on experiences in the environment of obstetric care and assumed the content of positive values arising from the humanization process, in which the limitation of studies relating obstetric care to the theoretical framework in question was perceived; these mostly addressed the values of breastfeeding and education ${ }^{(4,6,15-17)}$. Therefore, it was necessary to investigate this field of women's care. Thus, the following guiding question was used:What are the evaluative meanings of health professionals in the work process in relation to humanized delivery and birth?

The values for humanity (person) are in line with science, respect, and social justice ${ }^{(24)}$. In humanization, there is encouragement so that women's values and expectations are respected, such as the life of the woman and the baby in light of the physiology of parturition, with the support of a qualified, safe, and scientific evidence-based professional practice as a way of caring in collaboration with the people involved ${ }^{(1-2,14,19)}$. In this sense, based on the humanized model for delivery and birth, health professionals translate into their daily lives values that can be favorable or contrary to the needs of pregnant women ${ }^{(1-2,11,19-20)}$.

\section{OBJECTIVE}

To understand health professionals' values in the process of thinking and feeling about obstetric care, based on their experienced needs in the care process.

\section{METHODS}

\section{Ethical aspects}

The study was approved by the Research Ethics Committee from Hospital Universitário Antônio Pedro (HUAP) [Antônio Pedro 
University Hospital] of the Universidade Federal Fluminense (UFF) [Fluminense Federal University]. Voluntary participation was guaranteed by signing the Informed Consent Term (ICT). To preserve anonymity, respondents were given an alphanumeric coding (PS1, PS2, PS3, ...PS48).

\section{Theoretical-methodological framework and study type}

Phenomenological study, supported by Max Scheler's Theory of Hierarchy Values, for a valuative understanding ${ }^{(24)}$. The chosen theoretical framework portrays that values exist a priori, as they prevail for man, are independent of any personality of those who carry them, and are apprehended through a process ${ }^{(24)}$. Values are present in the lives of health professionals, influencing their actions ${ }^{(27)}$. The perception of being in the world, represented here in childbirth care, enables access to values, which are based on their feelings. Values are ranked in categories in ascending order: 1) useful values; 2 ) vital values; 3 ) spiritual values, which include aesthetic/moral, ethical, intellectual (logical) values; and 4) religious values ${ }^{(24-27)}$.

This article highlights the values of obstetric care in line with the humanized model. The writing of the study followed the criteria presented in the Consolidated Criteria for Reporting Qualitative Research (COREQ) ${ }^{(28)}$, which aims at the quality and transparency of reporting on qualitative health research.

\section{Study scenario}

The research was carried out in maternity hospitals of public SUS [Brazilian Unified Health System] hospitals in the Metropolitan Region of the state of Rio de Janeiro, namely: Hospital Estadual Azevedo Lima; Maternidade Municipal Dr. a Alzira Reis Vieira; Maternidade Municipal Dr. Mario Niajar. The scenarios were chosen according to the criterion: being a public institution with more than one thousand births/year.

\section{Data sources}

Around 36 professionals were eligible for participation (18 obstetricians and 18 obstetric nurses) in each maternity hospital, this number of professionals were provided by management. Then, recruitment by convenience was carried out, with the invitation being made with the presentation of the objective and information about the study. Data collection was carried out by the main researcher in each maternity hospital during the work shift of the surveyed professionals.

At that time, the following inclusion criteria were applied: being an obstetric nursing professional and an obstetrician; and act in the care of women in the delivery and birth process. Professionals with less than six months of service were excluded.

After applying the criteria, eligible participants were invited for an interview. The collection was terminated due to sufficiency of meanings ${ }^{(29)}$; specifically, when the concurrently developed analysis indicated that the meanings obtained responded to the research objective, that is, the inclusion of new participants was no longer necessary. So, the number of participants was not predetermined and totaled 48 health professionals, of which 12 were from each maternity hospital, with 6 from each professional category participating in the study.

\section{Data collection and organization}

One of the main instruments for approaching the phenomena is the phenomenological interview ${ }^{(29-30)}$, which provides access to the meanings of the study participants. The interview began with asking objective questions to characterize the participants (gender, age, graduation from an institution, length of experience in the obstetric area). This was followed by a triggering question, namely: "Talk about your daily care with women in the process of delivery and birth."With this, we sought to apprehend the values expressed by the participants in obstetric care. During the interview, the researcher adopted a position of listener and, at the same time, stimulator, so that, when he felt the need for more information, he asked the interviewee to talk more about the subject in question ${ }^{(30)}$.

Data were collected individually from April 2017 to April 2018, at the participants' workplace, in a private room (office) in the health units, with the presence of the main researcher and the participant only, ensuring the non-interruption of the dialogue. The interviews were carried out in a single moment with each participant, with an average duration of 45 minutes each. The speeches were audio-recorded on a digital device, with prior authorization from the participants, and later transcribed verbatim. Then came the treatment of the material.

\section{Data analysis}

The analysis was developed according to the Interpretation Theory ${ }^{(31)}$ and followed these steps: 1) Initial reading, in which the main researcher listened to the audio-recorded material, read the transcript, and made the first readings of the written text, free of judgment, in search of the relationship between the production of meanings (in the interview) and its first apprehension (in reading the transcripts), followed by highlighting, in the text (with color), the first identified meanings; 2 ) Critical reading, when the word, sentence, paragraph, and the text as a whole (discourse) were read in order to expand the apprehension of meanings (other meanings identified by the researcher were highlighted in color) and their organization (chromatic coding was used for similar meanings with empirical categorization to form the meaning units and their respective meanings); 3) Appropriation, developed through the interpretation of the meanings of health professionals in relation to obstetric violence, based on the Theory of Values ${ }^{(24)}$. The participants' speeches were discussed based on scientific evidence.

\section{RESULTS}

The health professionals were 24 obstetric nurses and 24 obstetricians, 39 women and 9 men. Regarding age, the majority (26) were between 30 and 50 years old; 14 were over 50 years old; and 8 were between 20 and 29 years old. Most (32) graduated from a public institution; and 16, from a private institution. Regarding the time working in the obstetric area, the majority (20) had been working for over 10 years; 15 had been working for less than 5 years; and 13, between 5 and 10 years of experience. 
The results pointed to the unit of meaning: the value of humanization in delivery and birth. The evaluative expression of health professionals with regard to care during delivery and birth is essential, as they unveil the experiences that give new meaning to values by identifying changes in the scientific field, of policies, protagonism, autonomy, expectations and satisfaction of women. Thus, value is attributed to the humanized model, which is expressed in the vital values and in the ethical and moral values of care for women during childbirth and birth.

This unit of meaning included the following meanings: 1) The vital value in humanized obstetric care; 2 ) The ethical value of obstetric care: sympathy for the care of others.

\section{The vital value in humanized obstetric care}

The meaning of speech expresses the growth and development of the health professional as a vital agent for care and points to the appreciation of the centrality of physiological processes, based on scientific knowledge.

In humanized childbirth, we try to provide qualified care [...] always provide individualized care, with the analysis of the clinical, obstetric, emotional part, always trying to give humanized care to the patient, in each case, following the evidence. (PS06)

It has changed a lot during my almost 30 years of maternity [...] the delivery, we saw it as a surgical patient and today we face it in a more physiological way [...] leven think that the name "normal childbirth" is something that should no longer exist, it must be a physiological birth [...] creating conditions that favor physiology: this translates into security for the woman. (PS34)

Childbirth is a natural event that takes place physiologically, it is a moment of extreme transformation for the woman/mother and for the child, obviously, respecting physiology, as we must be aware of any physiological change: this is vital. (PS18)

Physiology is recognized as a value in itself as it applies to the natural childbirth process. It is possible to notice the apprehension of the vital value, essential for the recognition of the healthy and physiological value. In addition to offering conditions to understand well-being as inherent in the life of the woman and her baby, this apprehension attributes to them the essential value of life.

Professionals also express humanized obstetric care when they recognize the distinction between normal, meaning physiological, as a natural event, and normal referring to the norm or routine, as an event crossed by excessive interventions and unnecessary manipulations of the woman's body.

Natural childbirth, it is just perfect, physiological, it is not normal childbirth [...], because, as we here [in the maternity hospital] end up following the woman since the beginning of labor [...], so we follow all the phases of it, when she arrives excited about this childbirth, when she feels pains, so we are monitoring, stimulating, explaining step by step. It is not routine: each woman is unique; this care guarantees well-being. (PS10)

The speeches reinforce the vital value as a desirable wellbeing for all human beings who value their existence in life and, simultaneously, express their emotional feeling, giving meaning to their well-being to guarantee their health at the time of delivery and birth. The humanized model of delivery allows us to bring a new value perspective to the understanding of parturition as a natural process, redefining the professional's values in obstetric care.

\section{The ethical value of obstetric care: sympathy for the care of others}

The professional values care centered on women's autonomy and freedom in their way of giving birth and provides an opportunity for informed choice, supported by scientific evidence, to maintain care safety. These attitudes point to the redefinition of values in obstetric care and reinforce the humanized model.

\begin{abstract}
"Let's squat for a bit." But here, I've even talked to the medical coordinator, our boss has a stool that is very useful during labor, that she [woman] can sit on the stool, and you can have a family member or a professional behind her so that he can support her in an upright position to facilitate, but he said he will provide, that the work is ongoing. (PS25)
\end{abstract}

So, we try to value the patient's choices [woman] from the beginning, I understand the changes [...] humanization should be the focus, with individualized care for the woman, reaffirming the values of scientific evidence. (PS27)

\begin{abstract}
It is also known that the lying position is not a position that favors physiology, it is the traditional one, but in fact it is not the most natural childbirth, the position that women usually instinctively assume for childbirth, when by herself, is either on all fours or crouched [...]. It is usually more vertical than lying down, but lying down has become the norm, so sometimes the person will remember that they saw on television that you should be lying down: "I'm going to lie down!" But instinctively it is not, so much so that the woman, when she is in contraction, she prefers to be sitting or walking or squatting, gives a better relief, in the hips, in the position and relaxes more. (PS46)
\end{abstract}

Such discourses value the professional's ethics, in which the value is consistent with emotional intuition. Health professionals point to the ethical value, which, through friendly care, understands the feelings of the other, is affected by the other, and engages in affective exchanges.

Ethics becomes a value that enables better health practices, such as the affectivity of care, producing a sympathetic relationship. In this way, such meanings express a redefinition of labor and birth as something beautiful, unique, and rediscovered, strengthening the humanization of health as an ethical value for obstetric care:

Childbirth is the most beautiful thing the human body can do, it's a time when a woman rediscovers herself as a person, it's a time when a woman rediscovers herself as a mother, she realizes that she can give birth. (PS36)

This moment of delivery and birth for me is unique. We professionals must be on the side of the woman, with the woman, this is ethical. The scientific evidence clearly shows this; this is a fundamental value for safe and ethical care. (PS44) 
Health professionals show the importance of dialogue as a relationship process for qualified care. Such dialogue enables the creation of a bond and a relationship of sympathy, as it reveals itself in an affective relationship with the woman, with her care and her health. Only when the bond is determined is it possible to empathize with the other.

A qualified care is correlated with our ethics, so, in a humanized model, we must create a bond with her [woman], so that we can welcome, listen, interact, create bond and affection with this woman and so that she [woman] feels safe with our actions in caring for her. (PS01)

I think dialogue is essential, as we have several women from different sociocultural or socioeconomic levels [...] you have to talk, understand what the woman says, but I think basically you have to have a good doctor-patient relationship with dialogue and affection. (PS43)

Thus, the ethical value is incorporated in the way in which health professionals act with women and take care of them, in which the affection of being with the other and taking care of the other is established. Sympathetic care is aimed at the other (parturient) in its integrality of being a woman giving birth and becomes possible when it is directed towards the woman's individuality.

\section{DISCUSSION}

The valuative expressions revealed by the interviewees' speeches in this study made it possible to discuss the vital-ethical value of humanized obstetric care for the care of others ${ }^{(32)}$. First, it is mentioned that health is a vital value, effectively translated as something essential to well-being. This value experienced by the care of nurses and doctors in the daily life of maternity hospitals is related to the Schelerian valuative sense ${ }^{(24)}$, in which man's emotional intuition allows him to make an immediate reference to the object (value), which is a fruit of existential scarcity ${ }^{(25-26)}$. The search for the vital value, which the humanized model offers health professionals in their search for fullness, favors the professional's development and growth. Thus, the object is valid for the human being, as this, in fact, fulfills their needs.

It is noticed that the health professionals' discourses are directed towards a new meaning (a new meaning by the new worldview), encompassing humanization as a process to ensure vital value ${ }^{(24-25)}$. The humanized model reinforces the openness to vital care for women and their babies. In this transition, the obstetric model is configured in faceted values: vital values are based on values centered on physiological processes, that is, on a primordial value to ensure human life.

Thus, humanization dialogues with vital values while aligned with the well-being of women and babies ${ }^{(24)}$, with emphasis on the reduction of medicalization, specifically of elective cesarean sections, and the elimination of care techniques that limit and harm the physical freedom of women in labor ${ }^{(2,7-12)}$. Humanization, in the participants' discourse, reinforces the vital value expressed in ensuring the centrality of care for women within the field of physiological birth processes, in which it constitutes a value in itself ${ }^{(24-26)}$, ensuring the well-being of the mother-infant binomial.
This is expressed in the change in the meaning of parturition as a no longer a normal event (norm or routine), full of unnecessary interventions, but in the understanding of a physiological birth, enabling greater dialogue for shared and focused decisionmaking for the integrality of care for women ${ }^{(2,14,19-21)}$. Thus, the humanization model strengthens this sense of new meanings of professional practice in obstetric care, with its exercise centered on the physiological processes of delivery and birth.

A highlight of these changes in practices and knowledge is related to the influence of proposals made by public policies, such as the NHP and, especially, the Estratégia Rede Cegonha [Stork Network Strategy], which reaffirm the vital value of childbirth ${ }^{(24)}$, supported by the recognition of the centrality of the physiological processes. Thus, vital values constitute the basis of professional practice, guided by the value of life, with well-being and safety as milestones for achieving the fullness of healthy life ${ }^{(16-24)}$. It is worth emphasizing that the value of sensitivity, correspondent to well-being, is significantly interpreted by health professionals in the field of the centrality of the physiological processes of childbirth and is in line with the humanized model. This leads to an understanding of the vital value as the potential of obstetric care, in order to carry out delivery and birth with an individualized and safe monitoring ${ }^{(7-9,14,19,24-29)}$.

Thus, the transition from the obstetric model becomes an essential need for the transformation of delivery and birth care, according to the speeches of health professionals. Therefore, this attention is based on values combined for well-being, vital values, that is, essential to life ${ }^{(24)}$. These values are also present in the alignment of public health policies in the obstetric field. Vital values are inherent to human dignity, in the autonomy of giving birth, with respect for their choices, aligning them with the value of justice and the right to life ${ }^{(24-25,33)}$.

This recognition is also consolidated in the valuation of science to ensure qualified care, because when health professionals support their performance by scientific recommendations ${ }^{(2)}$, the value of life is perpetuated, guaranteeing individualized care for safety. Finally, when professionals value humanization, they tend to recognize the sense of the vitality of their care as a vital essence for the other ${ }^{(24,32)}$. Therefore, the woman is recognized as a subject with autonomy in the act of giving birth, within her rights, and care as a value in itself, thus validating the safety of the parturient and the newborn ${ }^{(1-2,7-14,24-26)}$.

There is an appreciation in the speeches of health professionals when they bring scientific recommendations $s^{(1-2,7-11,21)}$, which qualify the care practice for normal childbirth centered on the needs of women, classifying it into categories related to the need of each woman, recognizing the uniqueness and particularity of care, and enabling the professional's development. Consequently, the founding value (vital) aims to encourage the adoption of useful care $^{(24-26)}$ instead of harmful and/or ineffective practices, which should be avoided and abolished in the daily routine of maternity hospitals. Thus, when individualized care is proposed, valuing science and feelings, the routine established by the technocratic model that values the same standard of care for all women in labor is broken; it is opposed to the serial parturition process. Thus, humanization allows this scientific evaluative intuition, based on the vital value and training (search for knowledge) as 
a humanistic process, an education focused on the knowledge of the spirit ${ }^{(1,9-12,21,24-26,34)}$.

Therefore, to consider the ethical value ${ }^{(24,32)}$ in the parturition process is to value the well-being of delivery and birth, an attention that facilitates openings for the emotions and feelings of the woman who experiences childbirth. These processes affect her emotional existence, and her self-esteem is expressed beyond reason ${ }^{(24-26)}$, influencing her autonomy to give birth. In this way, the professional recognizes the value of humanization and finds an echo to implement humanized care, which is fundamental for the establishment of ethical value ${ }^{(32)}$ and is established in the development of the feeling on the part of the health professional towards life and towards the woman. Ethical value allows professional conduct to contribute to shared care: for example, this occurs when it promotes freedom in women about how to give birth, encouraging more upright positions, such as squatting and stool delivery, which ensure more comfort and well-being of parturition; thus, horizontal birth is avoided as the traditional form of birth and, consequently, interventions in the birth scene.

Ethical values ${ }^{(32)}$ are intrinsically linked to the achievement of a congruent dynamism for qualified and safe care, supported by the value of scientific evidence (ethics vs. scientific evidence), which are captured by the daily life of maternity hospitals in the full exercise of care practice associated with the value of

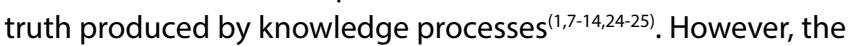
transgression of ethical values is shown in behaviors contrary to science, not guaranteeing the woman's existence and care, nor her freedom, as proposed by humanization ${ }^{(27)}$.

Thus, the meaning of obstetric care is established in affectivity as a facet of ethical value ${ }^{(2,21,24,32)}$, in listening to women who want more vertical positions, enhancing a safe birth and inhibiting unnecessary interventions. This care centered on dialogue enhances trust and provides opportunities for sharing decisions, with co-responsibility and promoting autonomy for the experience of a pleasurable birth, with values incorporated by humanization ${ }^{(11-14,19-20,24-25,35-36)}$.

As for the meanings of health professionals in labor and birth, the ethical value ${ }^{(24,32)}$ was shown through a sympathetic care (affection) towards the other ${ }^{(24-25)}$. This ethical value is established in the relationships between the woman and the health professional, in which, with the professional's intention to affect the other, an approach to the woman is developed ${ }^{(16-19,24,29,32,37)}$.

This Schelerian conception ${ }^{(24)}$ sustains that, through affection, the ability to sympathize with the other is established, perceiving them as human and not as a mere object. This is an important position for the principles that govern humanization, with respect for women and their individuality, uniqueness, autonomy, and creation of bonds as the purpose of carrying out behaviors based on humanization ${ }^{(24-26,32,37)}$. Ethical values are mediated by labor acts that consolidate the good of a given society, collective of people or individual(24-26,32,37). Thus, these are superior values, the value of human life and the spiritual value, which is why they become essential and healthy values for humanity ${ }^{(24)}$, here represented by the act of watching the parturition process.

In this way, humanization is articulated with the ethical value ${ }^{(32)}$ and enables an essay for a care based on affection, enhancing the use of values to the other, in health care, even revealing the construction of values in the sympathetic care ${ }^{(24-25)}$. That is because, to empathize with the other is to establish a dialogue, with the creation of a bond, unifying an affective act that motivates the action to care for the other (understand what the other is going through and how) ${ }^{(32)}$.

It is understood, therefore, that the discourses of health professionals confirm that humanization is supported by the ethical value in affective care ${ }^{(32)}$ and unique with the other. This exercise in the subjectivity of caring for the other (sympathy) considering effective obstetric behavior provides a unique care. Since this care for the other is an affective impulse, whose first manifestation is the being's sympathy for oneself and for the other, it implies multiple transformations with the subjects involved (the woman, the partner, and the family), thus strengthening affective, social, and spiritual relationships ${ }^{(26,32,37-38)}$. This leads us to recognize that women have their own knowledge about their bodies and that their knowledge must be shared in the parturition process, in order to guarantee the ethics of comprehensive care ${ }^{(1-2,7-14)}$.

It can be deduced that the ethical value ${ }^{(24,32)}$ is conceived as a care, based on a unique experience, which requires our respect, affection, and love, when considering the issues concerning the preservation of the other as a human being. Responsible ethical care can be seen as a universal value ${ }^{(32)}$. Therefore, ethical value becomes a transforming essence of daily practice, and it must be present with the other person, exalting their human rights ${ }^{(25-27,32,37-39)}$.

The person is the center of all ethical foundations, and genuine acts of sympathy display a positive ethical value ${ }^{(24,32)}$. Sympathy is inseparable from aspects of care for the person ${ }^{(32)}$. So, the health professional, when attending the birth, is faced with meanings that are established as an affective connection with sympathetic care $^{(32,37)}$, he understands his approach to the human being as a whole ${ }^{(32)}$ and with humanization, permeated by the approximation of the concrete meaning of birth as a value in itself.

Thus, it is necessary for the health professional to understand the value of obstetric care in its entirety when, by listening to the woman, he interacts with her anxieties and expectations. With this action, affectivity and creation of bonds are enhanced, as there is sympathy with the woman, and this sympathetic process with the other produces a more qualified, safe, and shared care. Thus, humanization allows health professionals to establish new meanings in parturition, based on vital and ethical care, being the link for women to be seen, heard, and understood with comprehensive care. In addition, the health professional, in their preferred evaluative dimensions, contributes to their intuitive act of reorganizing the hierarchy of values, being an essential situation for the transformation of their attitude in obstetric care.

\section{Study limitations}

As a study limitation, the institutional impossibility of carrying out a document analysis regarding the descriptions of care practices reported by professionals, that are available in institutional documents, is mentioned.

\section{Contributions to the field of Nursing}

It is noteworthy that care centered on vital and ethical values enables qualified and safe care, as valuing the pregnant woman is 
to feel and be with the other in its entirety. Thus, obstetric services must be aligned to give new meanings to the care of women in the daily parturition that the humanization model highlights.

Sharing health actions is a necessary value in the relationships between health professionals, managers, and users of the service. It should be guided by vital and ethical values, aiming to provide sympathetic care with others, with a focus on human rights, women's rights, justice, and scientific evidence, which cannot be disconnected from the health care process.

\section{FINAL CONSIDERATIONS}

Health professionals, collectively, unveil meanings about the humanization of obstetric care and discuss the potential of humanization as a means to change care, giving new meanings, aligned with vital and ethical values, established in affective relationships through the sympathetic process. They reframe their mode of care, based on humanization, and express the vital and ethical value as the foundation for this change, as opposed to the use of technocratic principles in parturition.

The redefinition of obstetric practice is articulated with public health policies, in the field of delivery and birth, with the insertion of the vital and ethical value for the lives of women and their babies, intervening in the way of caring for women. Qualified, safe and shared care is combined with affection, with care for the other.

\section{FUNDING}

Carlos Chagas Filho Foundation for Research Support of the State of Rio de Janeiro - FAPERJ.

Pro-Rectory of Research and Post-Graduate at the Federal University of Pará.

\section{REFERENCES}

1. Kottwitz F, Gouveia HG, Gonçalves AC. Route of birth delivery preferred by mothers and their motivations. Esc Anna Nery. 2018;22(1):e20170013. https://doi.org/10.1590/2177-9465-ean-2017-0013\%20

2. World Health Organization. WHO recommendations: intrapartum care for a positive childbirth experience [Internet]. Geneva: WHO; 2018 [cited 2020 Feb 14]. Available from: https://www.who.int/reproductivehealth/publications/intrapartum-care-guidelines/en/

3. Lopes M, Reis RR. Max Scheler: o conceito de pessoa e as críticas de Martin Heidegger. Ekstasis. 2016;5(1):14-33. https://doi.org/10.12957/ ek.2016.19509

4. Guimarães GL, Chianca TCM, Goveia VR, Souza KV, Quispe Medonza IY, Viana LO. The social value in nursing students' discourse: a phenomenological encounter with Max Scheler. Texto Contexto Enferm. 2016;25(3):e:2690015. https://doi. org/10.1590/0104-07072016002690015

5. Silva LA, Alves VH, Rodrigues DP, Vieira BDG, Marchiori GRS, Santos MV. The humanization of prenatal care under the pregnant women's perspective. Rev Pesqui Cuid Fundam. 2018;10(4):1014-19. https://doi.org/10.9789/2175-5361.2018.v10i4.1014-1019

6. Alves VH, Padoin SMM, Rodrigues DP, Branco MBLR, Marchiori GRS, Santos MV. Percepção das nutrizes acerca do valor útil do apoio ao aleitamento materno. J Nurs Health. 2018;8(3):e188306. https://doi.org/10.15210/jonah.v8i3.14166

7. Mouta RSO, Progianti JM. Process of creating the brazilian association of midwives and obstetric nurses. Texto Contexto Enferm. 2017;26(1):e5210015. https://doi.org/10.1590/0104-07072017005210015

8. Possati AB, Prates LA, Cremonese L, Scarton J, Alves CN, Ressel LB. Humanization of childbirth: meanings and perceptions of nurses. EsC Anna Nery. 2017;21(4):e20160366. https://doi.org/10.1590/2177-9465-ean-2016-0366

9. Amaral RCS, Alves VH, Pereira AV, Rodrigues DP, Silva LA, Marchiori GRS. The insertion of the nurse midwife in delivery and birth: obstacles in a teaching hospital in the Rio de Janeiro state. Esc Anna Nery. 2019;23(1):e20180218. https://doi.org/10.1590/2177-9465-ean-2018-0218

10. Pereira RM, Fonseca GO, Pereira ACCC, Gonçalves GA, Mafra RA. Novas práticas de atenção ao parto e os desafios para a humanização da assistência nas regiões sul e sudeste do Brasil. Ciênc Saude Colet. 2018;23(11):3517-24. https://doi. org/10.1590/1413-812320182311.07832016

11. Bourguignon AM, Grisotti M. A humanização do parto e nascimento no Brasil nas trajetórias de suas pesquisadoras. Hist Cienc Saude Manguinhos. 2020;27(2):485-502. https://doi.org/10.1590/s0104-59702020000200010

12. Lansky S, Souza KV, Peixoto ERM, Oliveira BJ, Diniz CSG, Vieira NF, et al. Obstetric violence: influences of the Senses of Birth exhibition in pregnant women childbirth experience. Cienc Saude Colet. 2019;24(8):2811-24. https://doi.org/10.1590/1413-81232018248.30102017

13. Oliveira RR, Melo EC, Novaes ES, Ferracioli PLRV, Mathias TAF. Factors associated to the type of childbirth in public and private hospitals in Brazil. Rev Esc Enferm USP. 2016;50(5):734-41. https://doi.org/10.1590/s0080-623420160000600004

14. Palharini LA. Autonomia para quem?: o discurso médico hegemônico sobre a violência obstétrica no Brasil. Cad Pagu. 2017;49:e174907. https://doi.org/10.1590/18094449201700490007

15. Guimarães GL, Chianca TCM, Quispe Mendoza IY, Goveia VR, Matos SS, Viana LO. The core values of modern nursing in the light of Dilthey and Scheler. Texto Contexto Enferm. 2015;24(3):898-905. https://doi.org/10.1590/0104-07072015003480014

16. Alves VH, Padoin SMM, Rodrigues DP, Silva LA, Branco MBLR, Marchiori GRS. Clinical management of breastfeeding: axiological value from women's perspective. 2016;20(4):e20160100. https://doi.org/10.5935/1414-8145.20160100 
17. Guimarães GL, Quispe Mendoza IY, Werli-Alvarenga A, Barbosa JAG, Corrêa AR, Manzo BF, et al. The art of nursing in the vision of the student: a meeting with Scheler. Rev Enferm UFPE. 2018;12(2):456-64. https://doi.org/10.5205/1981-8963-v12i2a23545p456-464-2018

18. Silva LA, Alves VH, Rodrigues DP, Santos MV, Guerra JVV, Marchiori GRS. Prenatal care: a value in question. Cogitare Enferm. 2017;22(2):e49548.: https://doi.org/10.5380/ce.v22i1.49548

19. Oliveira VJ, Penna CMM. Discussing obstetric violence through the voices of women and health professionals. Texto Contexto Enferm. 2017;26(2):e06500015. https://doi.org/10.1590/0104-07072017006500015

20. Amorim T, Araújo ACM, Guimarães EMP, Diniz SCF, Gandra HM, Cândido MCRM. Perception of obstetrical nurses on the care model and practice in a philanthropic maternity hospital. Rev Enferm UFSM. 2019;9:e8. https://doi.org/10.5902/2179769234868

21. Ministério da Saúde (BR). Diretrizes nacionais de assistência ao parto normal: versão resumida. Brasília, DF: Ministério da Saúde; 2017 [cited 2020 Dec 14]. Available from: http://bvsms.saude.gov.br/bvs/publicacoes/diretrizes_nacionais_assistencia_parto_normal.pdf

22. Assis TR, Chagas VO, Goes RM, Schafauser NS, Caitano KG, Marquez RA. Implementação da Rede Cegonha em uma Regional de Saúde do estado de Goiás: o que os indicadores de saúde mostram sobre atenção materno-infantil?. Rev Electron Comun Inf Inov Saude. 2019;13(4):843-53. https://doi.org/10.29397/reciis.v13i4.1595

23. Souza SAL, Silveira LMC. (Re)conhecendo a escuta como recurso terapêutico no cuidado à saúde da mulher. Rev Psicol Saude. 2019;11(1):1942. https://doi.org/10.20435/pssa.v0i0.571

24. Scheler M. Da reviravolta dos valores. 2a ed. Petrópolis: Vozes; 2012.

25. Pereira RMB. O sistema ético-filosófico dos valores de Max Scheler. Porto Alegre: EST Edições; 2000.

26. Cadena NB. Scheler, os valores, o sentimento e a simpatia. Rev Etica Filos Politica [Internet]. 2013[cited 2020 Oct 14];2(16):76-88. Available from: http://www.ufjf.br/eticaefilosofia/files/2009/08/16_2_cadena.pdf

27. Medeiros MB, Pereira ER, Silva RMCRA, Silva MA. Dilemas éticos em UTI: contribuições da teoria dos valores de Max Scheler. Rev Bras Enferm. 2012;65(2):276-84. https://doi.org/10.1590/S0034-71672012000200012

28. Tong A, Sainsbury P, Craig J. Consolidated criteria for reporting qualitative research (COREQ): a 32-item checklist for interviews and focus groups. Int J Qual Health Care. 2007;19(6):349-57. https://doi.org/10.1093/intqhc/mzm042

29. Paula CC, Padoin SMM, Terra MG, Souza IEO, Cabral IE. Modos de condução da entrevista em pesquisa fenomenológica: relato de experiência. Rev Bras Enferm. 2014;67(3):468-72. https://doi.org/10.5935/0034-7167.20140063

30. Silva DM, Silva RMCRA, Pereira ER, Ferreira HC, Alcântara VCG. Body perception among individuals with chronic kidney disease: a phenomenological study. Rev Mineira de Enferm. 2017;21:e1051. https://doi.org/10.5935/1415-2762.20170061

31. Ricoeur P. Teoria da interpretação: o discurso e o excesso de significação. Lisboa: Edições 70; 2013.

32. Alves VH, Barea R, Werneck VR, Grzibowski S, Rodrigues DP, Silva LA. Ethical care of the other: Edith Stein and Max Scheler's contributions. Esc Anna Nery. 2018;22(2):e20170382. https://doi.org/10.1590/2177-9465-ean-2017-0382

33. Souza AMM, Souza KV, Rezende EM, Martins EF, Campos D, Lansky S. Practices in childbirth care in maternity with inclusion of obstetric nurses in Belo Horizonte, Minas Gerais. Esc Anna Nery. 2016;20(2):324-31. https://doi.org/10.5935/1414-8145.20160044

34. Schulz A. Max Scheler: educar é humanizar. Rev Espaco Pedagogico. 2017;24(3):552-564. https://doi.org/10.5335/rep.v24i3.7765

35. Escobal APL, Matos GC, Gonçalves KD, Quadro PP, Cecagno S, Soares MC. Participation of women in decision-making in the process of parturition. Rev Enferm UFPE. 2018;12(2):499-509. https://doi.org/10.5205/1981-8963-v12i2a231114p499-509-2018

36. Badejoko OO, Ibrahim HM, Awowole IO, Bola-Oyebamiji SB, ljarotimi AO, Loto OM. Uprightor dorsal?: childbirth positions among antenatal clinic attendees in Southwestern Nigeria. Trop J Obstet Gynaecol. 2016;33(2):172-8. https://doi.org/10.4103/0189-5117.192219

37. Guimarães GL, Matos SS, Ferraz AF, Manzo BF, Sharry S, Souza MAF. Rediscover of the sympathy in the practice of the nurse in intensive therapy. Rev Enferm UFPE. 2017;11(2):491-7. https://doi.org/10.5205/1981-8963-v11i2a11966p491-497-2017

38. Gomes SC, Teodoro LPP, Pinto AGA, Oliveira DR, Quirino GS, Pinheiro AKB. Rebirth of childbirth: reflections on medicalization of the Brazilian obstetric care. Rev Bras Enferm. 2018;71(5):2744-8. https://doi.org/10.1590/0034-7167-2017-0564

39. Lobst SE, Breman RB, Bringham D, Storr CL, Zhu S, Johantgen M, et al. Associations among cervical dilatation at admission, intrapartum care, and birth mode in low-risk, nulliparous women. Birth. 2019;46(2):253-61. https://doi.org/10.1111/birt.12417 